\title{
Authentic subjectivity and social transformation
}

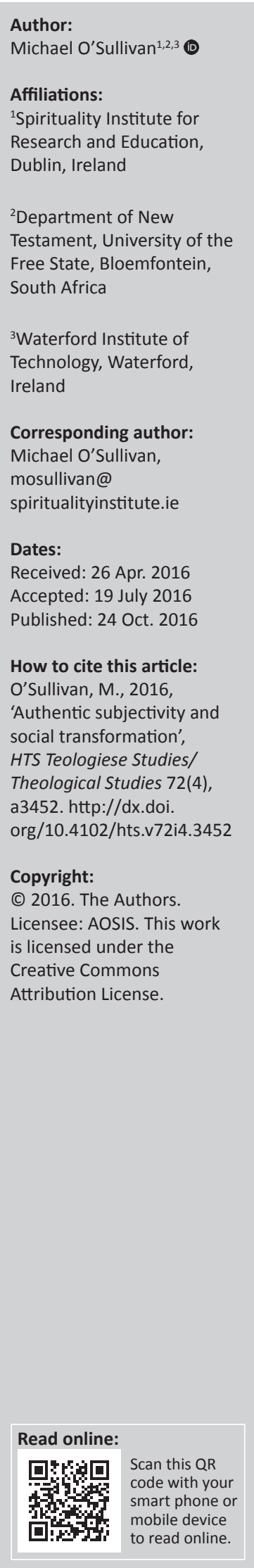

Holiness in the Christian tradition has often been understood in a way that devalues embodiment and practical engagement with the world of one's time. The latter understanding, for example, led to Marx's critique and repudiation of Christianity. Both interpretations of holiness can be understood as mistaken efforts to express the dynamism for authenticity in contextualised human subjectivity. Vatican 2 opposed both views by addressing itself to all people of good will, declaring that everyone was called to holiness, and that authentic Christian identity involved solidarity with the world of one's time, especially those who are poor. Vatican 2, therefore, provided an authoritative faith foundation for holiness expressed through social commitment and for viewing social commitment on the part of people of good will in whatever state of life as a form of holiness. This vision was also the conviction of leading spirituality writers of the period, like Thomas Merton, and inspired liberation theologians and the Latin American Catholic bishops at their conference in Medellín a few years after the Council. The argument of this article is that the emergence and development of a non-dualist Christian spirituality is grounded methodologically in the correct appropriation of the common innate dynamism for authenticity in concrete human persons and lived spiritual experiences consistent with and capable of enhancing this dynamism.

\section{Introduction}

The Second Vatican Council (1962-1965) spoke about a universal call to holiness (Vatican Council II, Lumen gentium / Dogmatic Constitution on the Church, para. 39). It also said that authentic Christian identity involved developing solidarity with the joys and hopes, the grief and anguish of the people of our time, especially those who are poor or afflicted (Vatican Council II, Gaudium et spes / Pastoral Constitution on the Church in the Modern World, para. 1). The Council, therefore, was particularly concerned to link the call to holiness with the need for solidarity in some form especially with the disadvantaged or afflicted. And its basis for doing so was its view of what constituted authentic companionship and discipleship of Christ.

\section{Karl Marx}

The Council's position would have surprised the 17-year-old Karl Marx (1818-1883) who wrote the following in an end of school essay many years earlier (Marx 1997):

The main principle which must guide us in the selection of a vocation is the welfare of humanity ... If a person works only for himself he [sic] can perhaps be a famous scholar, a great wise man, a distinguished poet, but never a complete, genuinely great man ... When we have chosen the vocation in which we can contribute most to humanity, burdens cannot bend us because they are only sacrifices for all. (p. 39)

Marx's words give us an insight into his inner life. They testify to how he is thinking, feeling, and imagining at a young age about his life ahead of him in relation to the world of his time. They show him moved by inner desire to be a 'genuinely great man' (my emphasis). They show that for him this meant dedicating himself to the welfare of humanity as a 'vocation' (my emphasis) and that this vocation would not be weakened by the sacrifices it involved because they would, as he put it, be 'sacrifices for all'.

At 18 Marx wrote (see Payne 1968):

Never can I be at peace, for my soul is powerfully driven

There had to be some fault in the universe,

The dumb agony of pain wrapped all round her,

Chained, eternally chained, eternally

We are the apes of a cold God. (pp. 61, 71) 
These words of the young Marx show that he experienced a powerful drive in his 'soul' (my emphasis) to transform the world of his time by breaking the chains imposed on it by what he called 'a cold God' (my emphasis).

Marx's passionate soulful words as a young man express what can be called his spirituality, understood as the determined and sustained desire to live authentically the first and only edition of himself. By living authentically I mean living from a state of relational self-presence of a particular kind. The kind of self-presence I have in mind is not static but dynamic. It is grounded in a capacity for self-transcendence that empowers the person to function in his or her common human knowing and choosing at the standard of receptivity, ${ }^{1}$ relationality, ${ }^{2}$ reflectivity, ${ }^{3}$ responsibility, ${ }^{4}$ and reflexivity ${ }^{5}$ that fidelity to beauty, intelligibility, truth, goodness and love, requires in the concrete. Let me illustrate this dynamic selftranscending capacity and its objective correlatives with an imaginative exercise.

\section{Imagination experiment regarding authentic subjectivity}

Imagine a person doing some quiet reading in a public park when suddenly she hears what sounds like a cry for help. If she is reflective in relation to experiencing that cry she will realise that experiencing the cry means her interiority is inherently relational in how it is constituted in the sense that it is naturally open to the wider world. This also means that how she receives the cry, and how she responds to it, will reflect her existing quality of self-presence which is foundational for how she relates to herself and the wider world. This quality of self-presence is also open to higher order transformation under the impact of lived experience, a point I will return to later.

So what does she do in relation to her experiencing of the cry? Is her reflexive and relational self-presence such that she ignores the cry, or is it of a quality that moves her to attend more acutely to the cry? In the case of the latter, does she find herself moved beyond the experience of hearing the cry to a higher form of self-presence that enables her not only to attend to the data that is the cry but also to seek an understanding of it by asking questions like, what does the sound I have heard mean? Does it mean that someone is in trouble, or does it, for example, mean that there might be a drama group nearby who are practising their roles? Given that both are possible, does she find herself being pushed or pulled to move on to a higher level again in herself

1.By 'receptivity' I mean the disposition and capacity to receive evidence in one's subjectivity that is consistent with beauty, intelligibility, truth, goodness, and love in life.

2.By 'relationality' I mean the capacity in one's subjectivity to connect to what corresponds to beauty, intelligibility, truth, goodness and love in the concrete.

3.By 'reflectivity' I mean the capacity to distantiate from the given for the sake of higher order attentiveness, insight, judgement, and decision-making regarding the given.

4.By 'responsibility' I mean the capacity to deliberate and decide in accordance with the standard of value and not simply according to what is convenient, pleasurable, satisfying or personal or group interest, which may cohere with the standard of what is truly good and lovable but are not foundational in what is decided.

5.By 'reflexivity' I mean the capacity to reflect on and evaluate the quality of one's receptivity, relationality, reflectivity and responsibility in terms of their correlation with beauty, intelligibility, truth, goodness, and love in life. where she is engaged in not only understanding, but also judging between different possible understandings? Which understanding of the situation is correct? This is a question rooted in a self-presence that relates to reality out of a desire for truth. If she finds that further question surfacing within her, does it not mean that there is within her a dynamism by which she can move from experience to understanding and beyond understanding to judgement and that the criterion to guide such movement is inherent in the movement? Staying with her practice of self-attention to her lived experience in the park, will she not find that the dynamism at work in her refuses to leave her content with knowing what is happening, but continues to prod her until she decides to act consistently with that discovered meaning of the cry? For example, self-attention discloses that if she discovers that someone really is in trouble there will arise from the interior ground of her subjective experiencing, interpreting, judging, and deciding, when it is functioning as it can, a desire or an imperative to do something about that situation by, for example, calling the police, or seeking the help of others who are also in the park.

Participation in this illustrative imagination-experiment provides grounds to affirm the reality of the structured operations of experiencing, understanding, judging, and deciding in common human and, therefore, gender-neutral, knowing and choosing. It also discloses that reality is a reality of meaning (reached in judgement) and value (reached in decision) and that reality is connected with methodologically, not by bypassing subjectivity as though reality was already out there now only waiting to be looked at, but by participating authentically in subjectivity.

We can call the desire for authenticity, the desire to be one's authentic self in and in relation to one's historical context (which, of course, is a far more complex reality than the one in the imaginative experiment, but the same process is involved in interacting with it), irrespective of the cost, a spiritual desire. When it is lived reflectively and reflexively it can be called the spiritual praxis of authenticity. This interior praxis regulates the relationship people have or form with the world and themselves. People receive, relate to, interpret, and respond to the world and themselves through the quality of their praxis of authenticity. This subjective praxis of being attentive to experience, of being willing to ask all the relevant questions, of refusing to settle for understanding that may not be correct, and of seeking to make and implement decisions that are consistent with the deliberation that follows upon such attending, understanding and judging, sets the standard for how people need to be in themselves if they are to correlate objectively with the historical world and their own reality to which they are always already connected. It makes people ask and answer along the journey of their lives: what am I saying and making of myself in the way I attend or refuse to attend to experience, in the way I question or refuse to question experience, in the way I judge or refuse to judge my understanding about my experience and that of others, in the way I decide to act, or refuse to act, on the basis of my judgement, and in the way I become, or refuse to become a better and more loving person. 
For Marx, living authentically in the context of his concrete reality came to mean a life dedicated to working out and articulating how the welfare of humanity could and would be realised through the dynamism of history. His theoretical system included in its predictions that Christianity would wither away. It would do so as the socio-economic and political conditions that gave rise to it were transformed into conditions of what I call beauty, intelligibility, truth, goodness and love, which have been differentiated in compact human experience over time. This transformation would occur as a result of people appropriating at last their interior and common human capacity to be, what I am calling, 'authentic', and acting collectively in accordance with that subjective and shared capacity.

This approach to the study of Marx's life and writings through the lens of spirituality being about perceived lived authenticity means that his life and writings can be conceived as being rooted in a soulful experience of being called, and driven even, to dedicate his life to the welfare of humanity and to cast aside in the process the God of his time as a cold God who did not empower the masses to transform their suffering but chained them to it.

Marx's initial judgement that God was a cold God was made in the context of a perceived soulful vocation to the welfare of humanity in what he called a universe wrapped in pain. His later judgement that God was not an independent reality of any kind but a socially constructed fantasy was made in a context in which the hegemonic form of Christianity in his time regarded a strong commitment to social transformation as a reductionism of authentic Christian faith.

Marx's dynamic desire for contextualised authenticity and the philosophy he developed in the light of it provided him, he concluded, with reasons and motivation to break away from the Christianity of his time. But was the Christianity he rejected authentic Christianity? What is authentic Christianity in the context of the struggle for social transformation? And was his position regarding the relationship between Christianity and the welfare of humanity derivative of a failure to self-appropriate his dynamism for authenticity correctly? Did he take account of all the data that needed to be considered regarding Christianity and the welfare of humanity, ask all the relevant questions about the relationship, settle only for the interpretation that did justice to the full scope of the data and the questions about it, and seek to implement decisions consistent with such judgement? This process of arriving at knowledge by beginning with attention to data and terminating with responsible and loving decisions does not exclude the place of belief, but beliefs that are accepted are accepted because of their resonance with the standard of authenticity and can then be part of what guides the dynamism for authenticity. His position was intelligible, perhaps, in the context of his time, but unyielding fidelity to the dynamism for authenticity in subjectivity and its objective correlatives of truth, goodness, and love calls for greater rigor and requires the revision of accepted positions in the light of further data and new insights.
I will argue that Vatican 2's linking of the call to holiness, and the expression of authentic Christian identity in terms of solidarity, especially with those who are poor or afflicted, contradicts Marx's position regarding what fidelity to the foundational dynamism for and standard of authenticity requires in a life. I will also argue that Vatican 2 contradicts the position of those within the Christian tradition who subscribe to what I call a reductionist worldview of Christian authenticity. This latter trajectory within the Christian tradition has not been the only one, but it has been the hegemonic one for long periods, has been exercising its influence from very early on, and continues to be prominent in the Christian community today.

\section{A form of inauthentic Christianity}

As an example of the prominence of this trajectory from early on, consider what Wiseman (2006:59) says regarding Origen (184/5-253/4 CE) on the Lord's Prayer:

[The] view of the corporeal and material, seeing it as not evil but as definitely of much lower worth than the spiritual, is evident in the way Origen comments on the verse about requesting 'our daily bread' in the Lord's Prayer. Whereas many writers today, especially liberation theologians, see this petition as integrally connected with the call to provide healthy food to the poor and undernourished of this world, Origen moves in a very different direction, asking:

How can the One (Jesus) who says we must ask for heavenly and great things have us ask for bread to be given for our flesh, since that is not a heavenly thing nor is the request for it a great thing? It would be as though He had forgotten His own teaching and ordered us to offer supplication to the Father for an earthly and small thing. (cf. Origen 1979:137)

\section{John Cassian (360-435)}

This kind of thinking is also not absent in John Cassian, a fourth-century monk, and the father of Egyptian monasticism. While he held that 'one's whole way of life and all the yearnings of one's heart become a single and continuous prayer', he also said in one of his works (transl. Ramsey 1997):

[I]t greatly hinders and holds back holy persons from the contemplation of that sublime good if they are taken up with what are still earthly pursuits even if they are good works ... If someone distributes sustenance to the poor or with gracious hospitality receives crowds of visitors, how is he [sic], at the every moment when he is being distracted and is anxious in the mind over the need of his brothers, to reflect upon the vastness of heavenly blessedness. (p. 784)

In its fuller and more unqualified sense this kind of thinking that I am pointing at holds that Christian spirituality is about orienting people to live now in a state of detachment from transforming the world, to accept their divinely ordained place, to accept being tested by suffering, and to be resigned to 'the will of God' regarding this life because an eternal reward is promised in the next. There is in this tradition a hierarchical dualism of spirit and matter, soul and body, and this world and eternity. Spirituality is a form of puritanism where the sacred and the holy, as they tend to be called, are 
about staying away from the mundane and the bodily. The spiritual is a reserved sphere, a sphere set aside; social and gender concerns are about commitment to a world and life that is passing away. Spirituality is about the 'above'; concern for social transformation is a form of reductionism (Battle 2007).

This form of Christian spirituality became the hegemonic form in Latin America following the Spanish and Portuguese conquest from 1492, despite the efforts of some, like the Dominican missionaries, to prevent it. A few examples will show its dominance.

\section{The Dominican Provincial}

Very soon after the arrival of the Spaniards the life of the indigenous people began to be destroyed. In 1511, on the island of Hispaniola (Haiti and the Dominican Republic), Friar Antonio Montesinos pronounced the following words on behalf of the Dominican community in a church service where leading officials were present (see Sobrino 1992):

With what right and with what justice do you hold these Indians ${ }^{6}$ in such cruel and horrific servitude; with what authority have you waged such despicable wars against these people who live meekly and peacefully in their lands and whom you have consumed in such infinite numbers with unheard of death and ruination? How do you hold them in such oppression and exhaustion, neither feeding them nor curing their ills which are the result of the excessive labours in which you force them so that they die? Or rather, you kill them, just to bring forth and accumulate more gold each day? (p. 2)

Gutiérrez, a pioneer of liberation theology and spirituality highlights that, following Montesinos' sermon, the superior of the Dominicans based in Spain wrote to the members of the Order in Latin America: 'The whole of India is ready to rebel because of your preaching, and neither we nor any Christian can be part of such a thing' (Gutiérrez 1981:4). He attributes the attitude of the missionaries to the sin which Satan introduced into history, and he reminds them that 'his Highness has acquired these islands by the right of war, and that his Holiness has made the King our Lord a donation of them, as a result of which he [the King] has every right to servitude'. He also forbids them to preach or publish without consulting the civil authorities where they are.

In another letter he gives the theological reason for all this that by preaching such things the friars were acting contrary to what made them go to Latin America, namely, 'the conversion of the pagans to faith in Jesus Christ and the wellbeing of souls'. In other words, as Gutiérrez points out (1981:4), 'to denounce the situation of exploitation of the Indians and to question the right to oppress, has nothing to do with salvation in Jesus Christ; it even goes against it'.

\section{Pope Pius VII, 1818}

As late as 1818, the year of Marx's birth, when the movement for emancipation from Spain was sweeping across the Latin 6.The Spanish believed they had landed in the Indies.
American continent, the Pope, Pius VII, wrote to the bishops of Latin America (see Miguez Bonino 1975):

... as one of the best precepts [of our religion] is that which enjoins submission to superior authorities, we do not doubt that in the riots that are taking place in these countries ... you will not have ceased to inspire your flock with the firm and righteous hatred which they must feel toward them (emphases mine). (pp. 7-8)

Pius' position regarding how to live Christian faith authentically in relation to the struggles in Latin America in that period was consistent with the hegemonic brand of Christianity that arrived in the continent with the conquistadores in 1492.

The continuing impact of this spirituality of disempowerment in the face of the need for social transformation is evident in the contemporary era, for example, in Religion and national security, a confidential document about the Catholic Church drawn up by the military dictatorship of General Pinochet in Chile in $1979 .^{7}$ It stated that the Chilean Constitution recognised the place of, not any church, but only that church which 'conceived its mission in terms of otherworldly salvation'. Unfortunately, the document continues:

[T] mean the substitution of evangelisation for the salvation of souls by a liberating, conscientising and politisising evangelisation. If there has to be liberating, conscientising and politisising evangelisation, it is alarming that such a mission is being exercised by foreigners ... It seems necessary to investigate, case by case, the immigration of priests in the last few years to see if they are responding to a premeditated plan to experiment with the fusion of 'Christians' and Marxists ... and finally the creation of a Communist State where the Church would survive in an utopian manner. ${ }^{8}$

This disempowering spirituality of otherworldly salvation is also very evident in the following conversation that took place in the Philippines at a time of unrest there in 1973, the same year as the military coup in Chile. Mary John Mananzan is a well-known Benedictine sister in the Philippines. Wiseman (2006) relates the following story about her:

When she had finished speaking to ten thousand people urging them to oppose a hike in the price of oil a policeman came up to her and asked: 'Aren't you a Sister.' After she said she was, he went on: 'So why are you talking about the oil price hike? You are a Sister. You ought to take care of the souls of the people. Why don't you talk about mortal sin, purgatory, hell?' (p. 181)

\section{Authentic subjectivity and authentic Christianity of social transformation}

So far I have been highlighting a form of commitment to social transformation that was dismissive of faith convictions (Marx) and a form of supposed Christian holiness that was

7.I was given the document to read when I worked in Chile as a Jesuit missionary priest. Pinochet, who considered himself a devout Catholic ruled from 1973-1989 following a bloody coup that ousted the elected Marxist President, Salvador Allende.

8.Because the document was a confidential document I do not have publication details for it. I had to leave Chile in May 1984 as a result of my stance with the people in Arica in the north of the country. 
disempowering in the face of social concerns. Neither position accords with the link that Vatican 2 makes between vocational holiness and social solidarity and the meaning, therefore, it gives to lived human and Christian authenticity. A third position that negates both of these positions and is aligned with the Council's non-dualistic position is needed.

It may surprise some to learn that St. Paul's use of the term 'spiritual' in his letters to newly established Christian communities not long after the death of Jesus provides a strong basis in the Christian tradition for a non-dualistic worldview so that the Council's position is not simply one of aggiornamento but also one of ressourcement. Paul did not contrast spiritual with bodily or material (see 1 Cor 2:13-3:3). For him spiritual did not refer to a part of the person or to life in certain restricted spheres. It referred, rather, to a way of being a whole person, of living the first and only edition of one's whole self as a personal life under the influence of the spirit of God's love. The opposite of 'spiritual' for Paul was a way of living as a whole person that contradicted this commitment (Sheldrake 1995:42-43; Perrin 2007:27).

\section{Thomas Merton and the turn to social spirituality}

Thomas Merton (1897-1968) in the contemporary era journeyed to a non-dualistic or holistic position. He 'gradually moved away from an early emphasis on contemplative withdrawal to a belief that the monastic life is a form of counter-cultural solidarity with those who struggle for social transformation and justice' (Sheldrake 2008:181).

In Merton's work The seven storey mountain in 1948, 'the monastery was an "enclosed freedom" where people are able to learn how to be happy away from the flux and unreliability of the everyday world'.

By the time of Life and holiness (1964), however, Merton had this to say:

The spiritual life is not a life of quiet withdrawal, a hothouse growth of artificial ascetic practices beyond the reach of people living ordinary lives. It is in the ordinary duties and labours of life that the Christian can and should develop his union with God ... Christian holiness in our age means more than ever the awareness of our common responsibility to cooperate with the mysterious design of God for the human race. (pp. 9-10)

In Conjectures of a guilty bystander (1966) Merton describes the experience of his unity with people in the centre of a shopping district in Louisville and communicates a more vulnerable sense of relationship 'to the world':

It was like waking from a dream of separateness, of spurious self-isolation in a special world, the world of renunciation and supposed holiness. The whole illusion of a separate holy existence is a dream. (p. 140)

These quotes show, as Sheldrake (2008) puts it, that:

Merton gradually came to understand that the monk was not a person who withdrew from 'the world', but was someone whose contemplative solitude was to be understood as a radically 'other' way of being in the world with a responsibility in and for that world. (p. 184)

Beneath Merton's shift was the dynamism for authenticity in his situated subjectivity and what fidelity to it required of him, as he saw it, in the first and only edition of his life.

\section{Liberation spirituality}

The most fruitful contemporary resource, however, for developing an authentic non-dual Christian spirituality concerning Christian faith and commitment to social transformation is to be found, I would say, in liberation theology and spirituality. This form of spirituality and theology which developed from the 1960s onwards did not develop from the subjectivity of a monk undergoing interior transformation under the dynamism for authenticity in the context of his continent and times. It developed instead from the cry of a whole people in the majority world seeking a radical transformation of their continent on the basis of a shared conviction in each one's subjectivity of God's preferential option for them (O'Sullivan 1986).

Their collective kairos (Gal 4:4) had come, and was recognised as such by the second general conference of Latin American Catholic bishops gathered at Medellín in 1968. This conference, which gave a huge impetus to the development of liberation theology and spirituality, said, 'Latin America will undertake its vocation to liberation at the cost of whatever sacrifice' (Second General Conference of Latin American Bishops 1979:23). These words regarding lived Christian authenticity in a post-Vatican 2 historical context in Latin America bear an uncanny resemblance to those of Marx back in 1835 when he wrote about his experience of a vocation to the welfare of humanity, the burdens of which would not bend because they would be sacrifices for all, which I quoted at the beginning of this article. The vocation to liberation that the conference of Catholic bishops at Medellín had in mind was a faith-based option with international roots, to transform socio-economic and political structures that imprisoned people in hunger, misery, denial of their dignity, etcetera. The bishops spoke of these effects as sinful, so that the vocation to liberation was a soteriological one (Second General Conference of Latin American Bishops 1979:33 fn. 3.), a vocation, that is, to participation in the work of salvation.

In order to live out this soteriological vocation, liberation spirituality has highlighted a very strong link between what Gustavo Gutiérrez from Peru, the founding father of this kind of spirituality and theology, calls contemplation and prophecy, prophecy in the biblical sense of deed-words or dabar directed at social transformation (Gutiérrez 1983; 1984). St. Ignatius of Loyola, the founder of the Jesuits, had spoken about finding God in all reality (Grogan 1996:2, 68) ${ }^{9}$ 9.See the "Contemplation to attain divine love', in The spiritual exercises of St. Ignatius of Loyola (Puhl 1951:101-103). 
and considered Jesuits to be contemplatives-in-action. ${ }^{10}$ Leonardo Boff from Brazil specified this insight further by calling for contemplation-in-liberation (Boff 1980-1981:372). The positions of Gutiérrez, Boff, Ignatius, and others like them, mean that in the context of Christian faith, fidelity to the dynamism for authenticity in lived subjectivity as shared by a whole people needs to be conceived as fidelity by them to a non-dualistic spirituality concerning the relationship between Christian faith and social commitment.

On this view of authentic Christian spirituality the Christian God is identified as the reality who, ultimately, originates, guides, sustains, and fulfils the transformative process of authentic subjectivity in persons, groups, societies, and traditions. This view makes foundational self-presence in and in relation to the world - authentic subjectivity - a form of spiritual practice because of what lies behind it, what it is rooted in, and where it is headed.

In a world where most of the known world is economically poor the spiritual process and practice of authentic subjectivity through which Christian faith gets expressed will proceed 'from below', to use Gutiérrez's phrase, that is, from the side of those who are treated as though they are not persons (O'Sullivan 2014a). It will commit one to what he calls 'the process of the liberation of the poor and oppressed ... realistically, and concretely', that is 'not only generously, but also with an analysis of the situation and a strategy of action' (Gutiérrez 1988:118).

\section{Conclusion}

Marx held that religion came into being as a social necessity for people who could not cope otherwise with their human situation, or who, if they were socially advantaged, used it to rationalise their privileges in the face of the misery of others. For him cultivating what I am calling the transformative effect of shared authenticity among people in and in relation to their historical situation promotes a praxis of social liberation which also results in the realisation that 'God' is not an independent reality and must be rejected for the sake of the welfare of humanity.

My argument, however, is that self-attention discloses that the praxis of inner liberation regarding how to function or perform in consciousness in the context of meeting the exigencies involved in knowing and choosing the true, good, and loving - an ascetical praxis of conduct - reaches a deeper ground than what Marx allowed. It shows that the selftranscending and normative dynamism for authenticity in the human spirit, if adhered to, is not confined to meaning and value within an immanent frame but transcends it. It embraces this world but the embrace evokes and points to meaning and value beyond this world and for this world. In the process it provides plausible grounds for believing that

10.The descriptor of Jesuits and those influenced by 'contemplatives in action' comes from a close collaborator and interpreter of Ignatius, Jerome Nadal. Along with the notion of finding God in all things it is considered to be at the core of Ignatian spirituality. See, for example, http://www. considered to be at the core of Ignatian spirituality. See, for example, http://www.
loyolapress.com/our-catholic-faith/ignatian-spirituality/introduction-to-ignatianspirituality/what-am-i-here-for-being-contemplatives-in-action
God is not a psychological projection or a socially constructed product.

Similarly, my argument rejects the worldview of a Christian spirituality that is not oriented to the transformation of life in this world on the grounds that it restricts the dynamism of the human spirit to less than its experienced scope for beauty, truth, goodness, and love and what God as love saw as good according to the book of Genesis. Solutions to the ordering of society that do not take account of this dynamic spiritual and religious make-up in people are not authentic solutions because they violate the integrity of the human spirit and repudiate the ways God has graced its socially transformative character in the lives of countless people, like Gutiérrez, Merton, and Dorothy Day.

Both worldviews can be understood as mistaken efforts to express the dynamism for authenticity in contextualised human subjectivity. Vatican 2 opposed both worldviews by addressing itself to all people of good will, declaring that everyone was called to holiness, and that authentic Christian identity involved solidarity with the world of one's time, 'especially those who are poor' (Gaudium et spes, para. 1). The Medellín conference and liberation theology gave further impetus and authority to this understanding of authentic Christian identity.

But as I have indicated in what I said above about Marx and Merton, for example, the capacity of the inherent praxis of authenticity to function as it can is always situated. It is dependent, therefore, not only on reliable guidance from authority but also on lived experiences and practices that reinforce, sustain, and direct it. In the absence of these the praxis can malfunction. An example from my own life of the deep formative effect of spiritual experience on the quality of one's lived self-presence and the choice of one's horizon of ultimate meaning and value may be helpful here. ${ }^{11}$

When my brother, sister and I were small children my father would come and say goodnight to us when he arrived home in the evenings. One evening, aged five, I remember him asking whether we had said our night prayers. I replied I had a toothache. Pausing ever so slightly he responded that I did not have to pray then as God would understand how I was feeling. Utterly unexpectedly his words immediately impacted on me in a way that led to a deep, warm, peaceful experience. I experienced myself in my embodied consciousness being reassured, being cared for; I experienced that my pain mattered, that I mattered - to God. I experienced and understood that God was a kind God, and that this profound realisation was being gifted to me from beyond myself. Reflecting on what happened that evening in later life has enabled me to identify this experience of spiritual consolation regarding the reality of God as a God of kindness being so powerfully transformative in my subjectivity that it became a

11.Other spirituality scholars who have written about similar experiences and their effects in their lives include Stephanie Paulsell (2008), Mary Frohlich (2009), and Janet Ruffing (2011). 
foundational criterion for me in how to be an authentic human being. Whatever was in line with that experience could be trusted, and whatever contradicted that experience had to be rejected or resisted.

It may be that Marx did not have experience of this kind in his childhood, despite his concern later on about the welfare of humanity and its rootedness in a commitment to live an authentic life. It may also be that the failure of Catholic Church leaders to intervene on the side of those who were suffering the effects of the conquest in Latin America at the end of the fifteenth century and the early years of the sixteenth century, or who were seeking political emancipation in the early nineteenth century from colonial rule, reflects a lack of experience of a kind God in their spiritual biographies or, because of the nature of their human and spiritual formation, a shunning rather than a welcoming of such experience if it took place. The present Pope, with his heroic efforts to make the Catholic Church a church of compassion and mercy is a shining example of a person whose common human receptivity, relationality, reflectivity, responsibility, and reflexivity function under the impact of a specific conversion to a kind and merciful God, and he has indicated this himself (O'Sullivan 2014b:295-296). He is living evidence of authentic Christian holiness in our time.

\section{Acknowledgements Competing interests}

The author declares that he has no financial or personal relationships which may have inappropriately influenced him in writing this article.

\section{References}

Battle, J., 2007, 'Editorial: Social spirituality: Monastic cell or hectic street?', Political Theology 8(4), 393-398.

Boff, L. et al., 1980-1981, 'The need for political saints: From the spirituality of liberation to the practice of liberation', Cross Currents 30(4), 369-376, 384

Cassian, J., 1997, John Cassian: The conferences, transl. and annotated by Boniface Ramsey, O.P., Newman Press, New York.
Frohlich, M., 2009, 'Under the sign of Jonah: Studying spirituality in a time of ecosystemic crisis', Spiritus 9(1), 27-45.

Grogan, B., 1996, Finding God in all things, Messenger Publications, Dublin.

Gutiérrez, G., 1981, 'En busca de los pobres de Jesucristo', Paginas (Separata) 38 (Junio), $12 \mathrm{pp}$.

Gutiérrez, G., 1983, 'Reflections from a Latin American perspective: Finding our way to talk about God', in V. Fabella \& S. Torres (eds.), transl. J. Drury, Irruption of the Third World: Challenge to theology, pp. 222-234, Orbis, Maryknoll, NY.

Gutiérrez, G., 1984, 'The task of theology and ecclesial experience', in L. Boff \& V. Elizondo (eds.), and M. Lefébure (English language ed.), transl. D, Livingstone, The people of God amidst the poor: Concilium 176, 61-64, T\&T Clark, Edinburgh.

Gutiérrez, G., [1971, Spanish] 1988, A theology of liberation, SCM, London.

Marx, K., [1967] 1997, Writings of the young Marx on philosophy and society, D. Easton \& K. H. Guddatt (transl. \& eds.), Hackett Publishing Co., Indianapolis, IN.

Merton, T., 1948, The seven storey mountain, Reprint, Sheldon Press, London.

Merton, T., 1964, Life and holiness, Doubleday, New York.

Merton, T., 1966, Conjectures of a guilty bystander, Burns \& Oates, London.

Miguez Bonino, J., 1975, Doing theology in a revolutionary situation, Fortress Press, Philadelphia, PA.

Origen, 1979, On Prayer 27:1 - An exhortation to martyrdom; Prayer; First Principles: Book IV; Prologue to the commentary on the Song of Songs; Homily XXVII on Numbers, transl. Rowan A. Greer, in The classics of Western spirituality, Paulist, Mahwah, NJ.

O'Sullivan, M., 1986, The saving grace of God's love as the basis for the option for the poor in the theology of Gustavo Gutiérrez, Unpublished MA thesis, University of Toronto (text is available in the Jesuit Library, Milltown Park, Dublin, Ireland and the Jesuit Library, Regis College, Toronto).

O'Sullivan, M., 2014a, 'The spirituality of authentic interiority and the option for the economically poor', Vinayasadhana 5(1), 62-74.

O'Sullivan, M., 2014b, 'The Jesuit spirituality of Pope Francis', Spirituality 20, 295-300.

Paulsell, S., 2008, 'Lost in the mystery of God: Childhood in the history of Christian spirituality', Spiritus 8(1), 83-96.

Payne, R., 1968, Marx, Simon and Schuster, New York.

Perrin, D., 2007, Studying Christian spirituality, Routledge, New York.

Puhl, L.J., SJ. (transl.), 1951, The spiritual exercises of St. Ignatius of Loyola, Loyola University Press, Chicago, IL.

Ruffing, J., 2011, 'An interview with Janet Ruffing', Presence 17(1), 6-12.

Second General Conference of Latin American Bishops, 1979, The church in the present-day transformation of Latin America in the light of the Council: Conclusions, 3rd edn., Secretariat for Latin America, National Conference of Catholic Bishops, Washington, DC.

Sheldrake, P., [1991] 1995, Spirituality and history, SPCK, London.

Sheldrake, P., 2008, 'Contemplation and social transformation: The example of Thomas Merton', in P.G.R. de Villiers, C.E.T. Kourie \& C. Lombaard (eds.), Acta Theologica suppl. 11: The Spirit that empowers: Perspectives on spirituality, pp.181-219, Publications Office of the University of the Free State, Bloemfontein.

Sobrino, J., 1992, '500 Years: Structural sin and structural grace' (Reflections for Europe from Latin America), 6 pages, shortened version of the talk given on 21 March 1992 at Salford Cathedral in Lancaster, England (complete text with references is available in SEDOS Documentation Centre).

Vatican Council II, 2014, Constitutions, decrees, declarations: The basic sixteen documents, A. Flannery (ed.), Liturgical Press, Collegeville, MN.

Wiseman, J., 2006, Spirituality and mysticism, Orbis, Maryknoll, NY. 